\title{
Assessment of Anti-Plasmodial Activity of Non-Hemolytic, Non- Immunogenic, Non-Toxic Antimicrobial Peptides (AMPs LR14) Produced by Lactobacillus plantarum LR/14
}

\author{
Ruchi Gupta • Vinoth Rajendran • Prahlad C. Ghosh • \\ Sheela Srivastava
}

Published online: 6 May 2014

(c) The Author(s) 2014. This article is published with open access at Springerlink.com

\begin{abstract}
Background and Objectives Lactobacillus plantarum strains are known to exhibit an antimicrobial property against bacteria and fungi. In the present investigation, AMPs LR14, antimicrobial peptides produced by L. plantarum strain LR/14, were tested against a protozoan system, Plasmodium falciparum and its non-toxic nature was envisaged on a mammalian system.

Methods Human erythrocytes infected with chloroquinesensitive and -resistant strains of P. falciparum were treated with purified AMPs LR14. The loss in cell viability was assessed by monitoring the incorporation of $\left[{ }^{3} \mathrm{H}\right]$-hypoxanthine in the nucleic acid of the parasite. The hemolytic activity of AMPs LR14 was monitored at different concentrations and the investigations into the in vivo toxicity of AMPs LR14 were carried out on a mammalian system (Wistar rat). The level of toxicity in the tissues was visualized by histopathological studies conducted on the liver and kidney of the test and control rats. A study was also undertaken to see the production of antibodies in an animal (rabbit) after it was immunized with AMPs LR14.

Results A loss in cell viability was observed in both test strains of $P$. falciparum. However, the dose required for inhibition of the chloroquine-resistant strain was $\sim 2$ times the dose required for the chloroquine-sensitive strain. At these concentrations, no hemolysis of human erythrocytes was observed. The studies conducted on in vivo toxicity of
\end{abstract}

R. Gupta $\cdot$ S. Srivastava $(\bowtie)$

Department of Genetics, University of Delhi South Campus,

New Delhi 110021, India

e-mail: sslab222013@gmail.com; sslab222012@gmail.com

V. Rajendran · P. C. Ghosh

Department of Biochemistry, University of Delhi South Campus,

New Delhi 110021, India
AMPs LR14 suggest that the lethal dose $\left(\mathrm{LD}_{50}\right)$ is beyond $1,000 \mathrm{mg} / \mathrm{kg}$ body weight, suggesting its safe use against microbes and protozoans. Antibodies were also not detected against these peptides, indicating a non-immunogenic nature.

Conclusion The data indicate that AMPs LR14 are nontoxic, potent anti-plasmodial peptides causing growth inhibition of $P$. falciparum without causing hemolysis. These results pave the way for the development of bioactive peptides as therapeutics.

\section{Key Points}

Lactobacillus plantarum strains are not known to exhibit anti-protozoan activity to the best of our knowledge. In the present investigation, the antiplasmodial activity of AMPs, LR14 antimicrobial peptides produced by $L$. plantarum strain $L R / 14$, was demonstrated on Plasmodium falciparum.

The lethal effect occurred only on the protozoan parasites and the erythrocytes remained unaffected by the peptide action.

Histopathological findings suggest that the extent of damage was negligible at the tissue level.

\section{Introduction}

Malaria, caused by a protozoan parasite, is considered one of the most important endemic diseases afflicting 
subtropical countries and is the ninth most significant cause of mortality globally [1, 2]. Of the four human malaria parasite species, Plasmodium falciparum has been rated as the most malignant and causative agent of cerebral malaria [3]. During the last few decades, there has been an emergence of clinical resistance to first-line treatment of antimalarial drugs. The widespread resistance of $P$. falciparum to chloroquine has rendered the drug ineffective against the most dangerous Plasmodium strain. Moreover, chloroquine resistance is associated with cross-resistance to other quinoline drugs, such as quinine and amodiaquine [4]. In the fight against resistance, artemisinin-based combination therapies (ACT) and its derivatives have provided a respite [5]. However, the search for novel lead compounds that can be developed as a cure for malaria is still active. One such group of compounds are peptides produced naturally or which are synthetic in nature $[2,6]$.

For its successful existence and to protect itself from other pathogens, bacteria synthesize antimicrobial peptides (AMPs). These AMPs are ribosomally synthesized and are generally known as bacteriocins [7]. They form an innate part of the lactic acid bacteria defense system [8, 9]. These peptides have remained effective weapons since times immemorial against bacteria and fungi. It is generally believed that resistance can be developed in microorganisms in response to a therapeutic molecule/compound; however, there are very few studies reporting the development of resistance against bacteriocins/AMPs. The reasons for this are that they are highly selective against the negatively charged bacterial membrane versus the zwitterionic mammalian membranes of a human host, and, secondly, the non-specificity in targeting is unlikely to evoke resistance [10]. The majority of reports suggest an association of these bacteriocins with the killing of pathogenic Gram-positive and Gram-negative bacteria as well as fungi [11-13]. Considering the inhibitory spectrum of these AMPs, they are turning out to be powerful agents for targeting bacteria, fungi, and parasites, and there may be other targets that they can be tested upon [6]. For any such application, it is mandatory to test and provide information on toxicity/ill effects of the compound under consideration. While humans are the endpoint beneficiary for all such applications, due to ethical reasons it is not possible to conduct toxicity testing directly on human beings; hence, toxicity tests on animals are conducted prior to human clinical investigations as part of the non-clinical laboratory tests of pharmaceuticals [14].

The present study aimed to explore the possibility of unravelling a safe and therapeutic alternative in the form of AMPs. Previously, we purified and described a two-peptide bacteriocin from Lactobacillus plantarum strain LR/14 exhibiting a wide antibacterial spectrum [15, 16]. Further, we have shown that the strain LR/14 produces additional peptides, AMPs LR14 [17]. The AMPs LR14 mixture was therefore purified by three-phase partitioning and gel-filtration chromatography; it appeared to contain four AMPs with a molecular mass less than $1 \mathrm{kDa}$ and to be devoid of plantaricins LR14- $\alpha$ and $-\beta$ (unpublished data). These peptides show antimicrobial effect against some pathogenic bacteria and fungi [18] and also probable insecticidal properties [17].

These peptides, AMPs LR14, were investigated for their efficacy against a human pathogen, P. falciparum. The study clearly demonstrates that the growth of the parasite was inhibited in a dose-dependent manner with almost negligible hemolytic activity. This is a preliminary study, but identifies an important lead that can be pursued further. Furthermore, we have conducted in vivo toxicity studies to evaluate its maximum tolerable dose and histological analysis of some tissues to suggest safe administration of AMPs LR14 if it is required to be tested in humans. We have also studied the immunogenic response of AMPs LR14 in a mammalian system.

\section{Methods}

\subsection{Source of Antimicrobial Peptides (AMPs) LR14}

L. plantarum strain LR/14 was maintained on MRS agar medium (de Man-Rogosa-Sharpe medium, HiMedia, Mumbai, India). The culture was raised at $37^{\circ} \mathrm{C}$ under static conditions for $24 \mathrm{~h}$. The culture supernatant was obtained by centrifugation at $6,000 \times g$ at $4{ }^{\circ} \mathrm{C}$ for $10 \mathrm{~min}$ and served as the source of crude AMPs LR14. For purification, proteins were precipitated by three-phase partitioning using ammonium sulfate and tertiary butanol. The protein precipitate appeared as an interfacial layer which was separated, washed a few times, and dissolved in sterile distilled water. This was further subjected to gel-filtration chromatography using Sephadex G-25 desalting columns (GE-Healthcare Bio-Sciences, USA). All chemicals used were of analytical grade, and all media used were purchased from HiMedia (Mumbai, India).

\subsection{Quantification of AMPs LR14}

Concentration of AMPs LR14 was determined using a BCA (bicinchoninic acid) protein assay kit, as recommended by the supplier (Sigma-Aldrich, USA). Antimicrobial action was assayed in terms of both qualitative [agar well diffusion assay (AWDA)] and quantitative (AU/ $\mathrm{mL}$ ) methods $[17,18]$. One activity unit (AU) was defined as the reciprocal of the amount of bacteriocin that inhibited the growth of the indicator organism by $50 \%$, when compared with the untreated control. 
AWDA was performed by overlaying soft nutrient agar $(0.8 \%)$ seeded with indicator strain $\left(\sim 1 \times 10^{6} \mathrm{cfu} / \mathrm{mL}\right)$ Micrococcus luteus on the NB base agar plate. The wells cut out $(6.0 \mathrm{~mm}$ diameter $)$ on such plates were filled $(100 \mu \mathrm{L})$ with the AMPs. Halo produced after overnight incubation was used as an indicator of growth inhibition. The antimicrobial ability of the peptides (AMPs LR14) was quantified in terms of activity units (AU/mL). For this, $150 \mu \mathrm{L}$ of NB, $50 \mu \mathrm{L}$ of AMPs LR14 at twofold serial dilutions, and $50 \mu \mathrm{L}$ of the culture of the indicator organism were mixed in different wells of a microtiter plate. These plates were incubated for $6 \mathrm{~h}$ at $37^{\circ} \mathrm{C}$ and the growth was measured spectrophotometrically at $630 \mathrm{~nm}$ using a microtiter plate reader (Bio-Rad, USA) and compared with an untreated sample.

\subsection{Drug Dilutions}

Stock solutions of AMPs LR14 and chloroquine diphosphate $(10 \mathrm{mg} / \mathrm{mL})$ were prepared in water (milli-Q grade). All stocks were then further diluted with incomplete RPMI-1640 (without serum) to achieve the required concentrations.

\subsection{In Vitro Culture of Plasmodium falciparum}

The strains of $P$. falciparum used in the study, 3D7 (chloroquine sensitive) and RKL19 (chloroquine resistant), were obtained from the National Institute of Malaria Research (NIMR), New Delhi, India. The strains were maintained by a modified method of Desjardins et al. [19] by serial passages in human erythrocytes cultured at $4 \%$ hematocrit in RPMI-1640 medium supplemented with $10 \%$ human serum and incubated at $37{ }^{\circ} \mathrm{C}$ under the atmosphere of mixed gases $\left(5 \% \mathrm{CO}_{2}, 5 \% \mathrm{O}_{2}\right.$, and $90 \%$ $\mathrm{N}_{2}$ ) in a plastic chamber. Heparinized whole $\mathrm{O}^{+}$blood was collected from the Rotary Blood Bank, New Delhi, India, and red blood cells (RBCs) were separated under sterile conditions by centrifugation to remove serum and buffy coat. The levels of parasitemia were routinely monitored on blood smear with $5 \%$ Giemsa-azure type B stain in phosphate buffer $(20 \mathrm{mM}, \mathrm{pH} 7.2)$. For each experiment, samples of the stock culture were further diluted in culture medium upto $2 \%$ hematocrit and $1 \%$ parasitemia.

\subsection{Evaluation of Anti-Plasmodial Activity of AMPs LR14}

Briefly, different concentrations derived from twofold serial dilution of AMPs LR14 $(0.6-42 \mu \mathrm{g} / \mathrm{mL})$ were added to $P$. falciparum-infected erythrocyte suspension (2\% final hematocrit and $1 \%$ parasitemia) in a 96-well tissue culture plate along with an untreated control. In another set, different concentrations of chloroquine diphosphate were added to infected erythrocyte suspension as the positive control. Negative control included media incubated with infected RBCs.

After $24 \mathrm{~h}$ of incubation at $37^{\circ} \mathrm{C}, 20 \mu \mathrm{L}$ of $0.2 \mu \mathrm{Ci} /$ well of $\left[{ }^{3} \mathrm{H}\right]$-hypoxanthine (American Radiolabeled Chemicals, Inc., specific activity $25 \mathrm{Ci} / \mathrm{mmol}$ ) was added to each well containing unsynchronized parasite culture. After $18 \mathrm{~h}$ of incubation, the cells were harvested onto a glass-fibre filter paper using a Skatron Semi-automated cell harvester [19]. The paper discs were placed in a $5 \mathrm{~mL}$ scintillation cocktail that consisted of ( $1 \mathrm{~L}) 0.1 \mathrm{~g}$ POPOP $(1,4$, bis $2-5$ phenyl oxazolyl benzene), $4 \mathrm{~g}$ PPO (2-5 diphenyl oxazole), $300 \mathrm{~mL}$ ethanol, and $700 \mathrm{~mL}$ toluene and stirred overnight. $\left[{ }^{3} \mathrm{H}\right]$-hypoxanthine incorporation in nucleic acid was measured in a liquid scintillation $\beta$-counter (Model: TriCarb 2900 TR, Perkin Elmer, USA). The cell viability was calculated by comparison with control, which consisted of complete medium as a substitute for the test molecule. The concentration of drug producing $50 \%$ inhibition $\left(\mathrm{IC}_{50}\right)$ values were determined by plotting the drug concentration versus the percentage cell viability of the parasite after $24 \mathrm{~h}$ of incubation. All data points were collected in triplicate for each independently conducted experiment.

\subsection{Assessment of Hemolytic Activity}

Hemolysis was measured in AMPs LR14-treated sets of cultured infected and uninfected erythrocytes by measuring the absorbance of hemoglobin at $405 \mathrm{~nm}$ [20]. Heparinized fresh blood was rinsed in phosphate buffered saline (PBS) (by centrifugation at $200 \times g$ for $2 \mathrm{~min}$ ) and resuspended in PBS at $4 \%$ hematocrit. Briefly, increasing concentrations of AMPs LR14 were added to P. falciparum-infected (2\% hematocrit and $1 \%$ parasitemia) and -uninfected erythrocytes ( $2 \%$ hematocrit) in a 96-well plate for $42 \mathrm{~h}$ at $37{ }^{\circ} \mathrm{C}$. After incubation, the plate was spun down briefly and absorbance of supernatant was read at $405 \mathrm{~nm}$. Mixing the erythrocytes with $1 \%$ Triton-X 100 (for $100 \%$ hemolysis) and PBS alone (for baseline values) served as positive and negative controls, respectively. Hemolytic activity data were obtained from at least two independent experiments.

\subsection{Evaluation of In-Vivo Toxicity of AMPs LR14 on a Mammalian System}

An acute oral toxicity test of AMPs LR14 on Wistar rats was carried out at the Shriram Institute for Industrial Research, Delhi, India. The studies were conducted in compliance with Good Laboratory Practices (GLP) in accordance with the OECD guidelines for testing of chemicals for non-clinical laboratory studies. 


\subsubsection{Experimental Design}

A batch consisting of female Wistar rats $(n=5$ per group per dose) (Rattus rattus albanicus), each weighing 160-180 g, were used for each test with different concentrations of AMPs LR14. Initially an acclimatization period of 5 days was given to the animals. The animals were administered with a single dose of the test substance (AMPs LR14). One control group with vehicle, i.e., normal saline, was also included in the plan of work.

\subsubsection{Method and Frequency of Administration}

The animals were fasted overnight prior to dosing and for $4 \mathrm{~h}$ after dosing. A batch $(n=5)$ was administered with a single dose of AMPs LR14 solution orally at a level of $50 \mathrm{mg} / \mathrm{kg}$ with the help of a canula attached to the syringe. One control group was administered with the vehicle, i.e., normal saline. Similarly, second, third, and fourth doses of $300,1,000$, and $2,000 \mathrm{mg} / \mathrm{kg}$, respectively, were given to different batches of each group. The test compound (AMPs LR14) was administered only once to the test groups, and the animals were monitored regularly for 14 days. Observations were made at least once during the first $30 \mathrm{~min}$, with special attention during first $4 \mathrm{~h}$ on the day of dosing and daily thereafter for a total of 14 days or until any adverse signs were observed. Body weights were recorded prior to dosing and weekly thereafter. All gross visible signs and symptoms were also recorded.

\subsubsection{Histopathological Analysis}

Representative samples of the liver and kidney were removed from the control and AMPs LR14 (1,000 mg/ $\mathrm{kg}$ ) administered group of animals. The formalin-preserved tissue sections were processed as follows: (1) fixation in $10 \%$ neutral buffered formalin for $1 \mathrm{~h}$, twice; (2) dehydration in graded series of alcohol $(70 \%$ for $30 \mathrm{~min}, 90 \%$ for $1 \mathrm{~h}$, and two cycles of $100 \%$ for $1 \mathrm{~h}$ each); (3) dehydration again with xylene for $1.5 \mathrm{~h}$, twice; and (4) impregnated in molten wax at $65^{\circ} \mathrm{C}$ for $2.5 \mathrm{~h}$ with two changes. The processed tissues were embedded in paraffin and sectioned ( $4 \mu$ thickness) and dried on a $70{ }^{\circ} \mathrm{C}$ hot plate for $30 \mathrm{~min}$. The tissues were stained using hematoxylin and eosin (H\&E) stains. The stained tissues were dehydrated with $70 \%$ ethanol followed by $90 \%$ ethanol, placed in two changes of $100 \%$ ethanol for $3 \mathrm{~min}$ each, and cleaned with two changes of xylene ( 3 min each). The morphological changes were monitored through a bright-field microscope (Leica TP1020, Japan).
2.8 Studies on Generation of Immune Response of AMPs LR14 in a Rabbit

A purified preparation of the peptide $(200 \mu \mathrm{g} / \mathrm{mL})$ was used to immunize a rabbit, followed by the booster doses $(100 \mu \mathrm{g} / \mathrm{mL})$ administered at an interval of 4 weeks. AMPs LR14 as an antigen was injected subcutaneously and the rabbit was bled after 4 months. Blood collected from the animal was subjected to ELISA in order to detect the formation of antibodies. Different dilutions $(10 \mathrm{ng} / \mathrm{mL}$, $100 \mathrm{ng} / \mathrm{mL}, 1 \mu \mathrm{g} / \mathrm{mL}, 10 \mu \mathrm{g} / \mathrm{mL}$ ) of the antigen (purified AMPs LR14) were added to a microtiter plate and kept for incubation at $4{ }^{\circ} \mathrm{C}$ overnight. The plate was washed with $0.01 \mathrm{M}$ phosphate buffer $\mathrm{pH}$ 7.2. Casein was added to all the wells and incubated at room temperature for $1 \mathrm{~h}$. Casein was removed from the wells and washed with $0.01 \mathrm{M}$ PBS. The plate was tapped gently on a blotting sheet.

Next, primary antibodies were added in different dilutions comprising $1 / 10,1 / 100,1 / 500,1 / 1,000,1 / 2,000$, $1 / 5,000$, and $1 / 10,000$. In one set, $1 / 10$ pre-bled antiserum was taken as the control. Washing was done again with PBS three times and the plate was tapped gently every time. Further, secondary antibodies [goat anti-rabbit IgG and horse radish peroxidase (HRP) conjugate] were added and the plates were incubated for $1 \mathrm{~h}$ at $37^{\circ} \mathrm{C}$. This was followed by three rounds of washing with PBS. The substrate $o$-Phenylenediamine (OPD) at a concentration of $10 \mathrm{mg} / \mathrm{mL}$ was added to each well and plate was incubated at room temperature for $30 \mathrm{~min}$. Absorbance was read at $490 \mathrm{~nm}$.

\subsection{Statistical Analysis}

The in vitro antiplasmodial experiments were conducted in triplicate and the results represent the mean of two independent experiments. The in vivo toxicity test was performed for $n=5$ per group of rats/dose per batch. Parameters such as body weight changes were tabulated and analyzed by Student's $t$ test.

\section{Results}

\subsection{Quantification of AMPs LR14}

The AMPs LR14 are a mixture of four peptides, and all the peptides have molecular masses $<1 \mathrm{kDa}$. These peptides show considerable antimicrobial activity against the indicator strain, $M$. luteus. The antimicrobial activity and protein concentration of the four peptides are as follows: peptide $1-12,500 \mathrm{AU} / \mathrm{mL} \quad(500 \mu \mathrm{g} / \mathrm{mL})$; peptide $2-$ $25,000 \mathrm{AU} / \mathrm{mL}(450 \mu \mathrm{g} / \mathrm{mL})$; peptide $3-25,000 \mathrm{AU} / \mathrm{mL}$ 
(700 $\mu \mathrm{g} / \mathrm{mL})$; and peptide $4-12,500 \mathrm{AU} / \mathrm{mL} \quad(700 \mu \mathrm{g} /$ $\mathrm{mL})$. These peptides are different from other bacteriocins known in the database as well as plantaricin LR14- $\alpha$ and $\beta$. Moreover, the retention time of any of these peptides (AMPs LR14) did not match with plantaricins LR14- $\alpha$ and $-\beta$, as confirmed by the high-performance liquid chromatography (HPLC) chromatogram [17].

These peptides have been characterized in terms of their heat and $\mathrm{pH}$ stability. They are tolerant to extremes of temperature ranging from boiling to freezing at $-20^{\circ} \mathrm{C}$. They are able to retain their activity in a wide range of $\mathrm{pH}$ values ( $\mathrm{pH} 2-10)$, and are susceptible to proteolytic cleavage, which confirms their proteinaceous nature.

\subsection{Evaluation of Anti-Plasmodial Activity of AMPs LR14}

P. falciparum takes up hypoxanthine as part of its purine salvage pathway and its incorporation is a measure of growth and viability of the parasite. Thus, the viability of the parasite can be monitored by the extent of incorporation of $\left[{ }^{3} \mathrm{H}\right]$ hypoxanthine. As described in Sect. 2, the infected erythrocytes incubated with different concentrations of AMPs LR14 along with $\left[{ }^{3} \mathrm{H}\right]$ hypoxanthine showed a dosedependent decline in the radioactive counts, reflecting the effect on the viability of the parasite.

Different concentrations of AMPs LR14 ranging from 0.6 to $42 \mu \mathrm{g} / \mathrm{mL}$ showed inhibition in the range of $1-99 \%$ in comparison with an untreated control (considered as $100 \%$ viable). From the results obtained, $\mathrm{IC}_{50}$ was achieved in the chloroquine-sensitive strain (3D7) at $1.6 \mu \mathrm{g} / \mathrm{mL}$ and the chloroquine-resistant strain (RKL19) at $2.85 \mu \mathrm{g} / \mathrm{mL}$ of AMPs LR14. In comparison, the $\mathrm{IC}_{50}$ level of chloroquine (positive control) was $17.6 \mathrm{ng} / \mathrm{mL}$ for the chloroquine-sensitive strain (3D7) and $100 \mathrm{ng} / \mathrm{mL}$ for the chloroquineresistant strain (RKL19). No hypoxanthine uptake could be detected beyond the maximum tested dose of $42 \mu \mathrm{g} / \mathrm{mL}$, where $99 \%$ inhibition was observed. Figure 1 depicts the percentage cell viability at different concentrations of AMPs LR14 used, in comparison to the control.

\subsection{Assessment of Hemolytic Activity}

In order to demonstrate that the anti-plasmodial activity of AMPs LR14 was not due to lysis of erythrocytes, hemolysis of infected and uninfected cells in response to AMPs LR14 treatment was also investigated. No hemolysis was observed in uninfected erythrocytes at different concentrations tested. However, in infected erythrocytes treated at $100 \mu \mathrm{g} / \mathrm{mL}$, hemolysis to the level of about $1 \%$ was observed (Table 1). There was no hemolysis even at $50 \mu \mathrm{g} /$ $\mathrm{mL}$, suggesting that the anti-plasmodial effect (as described above) was independent of any hemolytic activity.

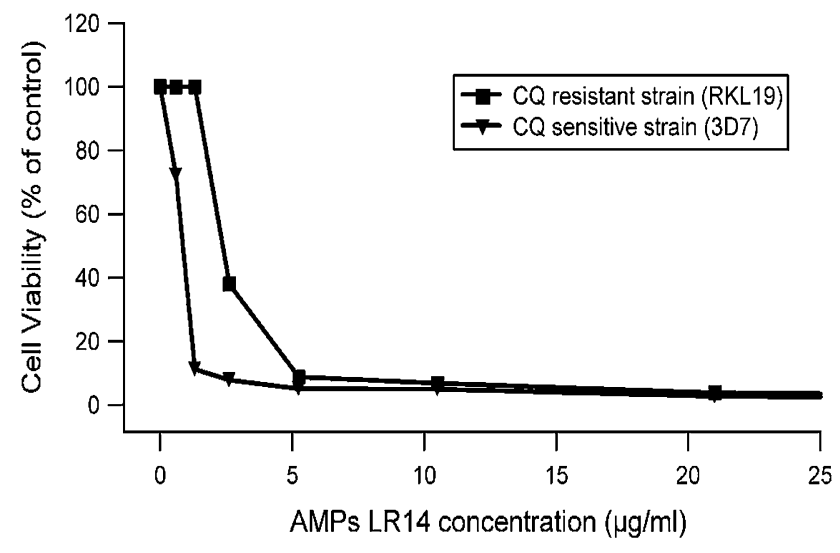

Fig. 1 Effect of antimicrobial peptides (AMPs LR14) on the growth of Plasmodium falciparum: P. falciparum-infected erythrocytes (2\% final hematocrit and $1 \%$ parasitemia) were incubated for $24 \mathrm{~h}$ at $37{ }^{\circ} \mathrm{C}$ in the presence of different dosages of AMPs LR14. The concentration of drug producing $50 \%$ inhibition was assessed by measuring the $\left[{ }^{3} \mathrm{H}\right]$ incorporation into nucleic acid of $P$. falciparum cells. Experiments were performed with two strains of $P$. falciparum: a chloroquine-resistant strain (RKL19) and a chloroquine-sensitive strain (3D7). The mean value \pm standard deviation is indicated for each group and values are representative of three independent experiments. AMPs antimicrobial peptides, $C Q$ chloroquine

\subsection{In Vivo Toxicity Test of AMPs LR14 on a Mammalian System}

If these AMPs are to be developed as a therapeutic molecule, it is important to study their toxicity. Therefore, we conducted an in vivo toxicity test on a mammalian system comprising Wistar rats. For this, the rats were administered with a single oral dose of different concentrations of purified AMPs LR14. All experimental animals (those treated and controls) were observed for 14 days. During this period, there was no significant difference in the body weights of untreated and treated animals at some of the doses of AMPs LR14, such as 50, 300, and $1,000 \mathrm{mg} / \mathrm{kg}(p<0.5)$. However, the rats fed with $2,000 \mathrm{mg} / \mathrm{kg}$ AMPs LR14 did not survive beyond 1 day, so their weights were not considered (Table 3).

The results obtained after conducting the test on rats provided an insight that under the given conditions no treatment-related toxic signs and symptoms/mortality were observed at the tested concentrations of 50 and $300 \mathrm{mg} / \mathrm{kg}$. On further increasing the AMPs LR14 concentration to $1,000 \mathrm{mg} / \mathrm{kg}$, shivering in the animals was observed after dosing, which subsided within $24 \mathrm{~h}$ and had no adverse effect thereafter. Therefore, no mortality was observed at this dose. However, on further increasing the dose concentration to $2,000 \mathrm{mg} / \mathrm{kg}$, symptoms such as ruffled fur, shivering, and ataxia were noticed in the tested group and the animals died within $4 \mathrm{~h}$ after dosing (Tables 2, 3). From these results, the lethal dose $\left(\mathrm{LD}_{50}\right)$ value of AMPs LR14 can be hypothesized to lie between 1,000 and $2,000 \mathrm{mg} / \mathrm{kg}$. 
Table 1 Effect of various concentrations of AMPs LR14 (antimicrobial peptides produced by $L$. plantarum strain LR/14) on the hemolysis of infected (1\% parasitemia) and uninfected erythrocytes for $42 \mathrm{~h}$ as described in Sect. 2

\begin{tabular}{|c|c|c|}
\hline \multirow{2}{*}{$\begin{array}{l}\text { Concentration of AMPs } \\
\text { LR14 (ng/mL) }\end{array}$} & \multicolumn{2}{|l|}{ Hemolysis (\%) } \\
\hline & $\begin{array}{l}\text { Infected RBCs (1 } \% \\
\text { parasitemia) }\end{array}$ & $\begin{array}{l}\text { Uninfected } \\
\text { RBCs }\end{array}$ \\
\hline 100 & $0.9 \pm 0.08$ & 0 \\
\hline 75 & $0.55 \pm 0.03$ & 0 \\
\hline 50 & 0 & 0 \\
\hline 25 & 0 & 0 \\
\hline
\end{tabular}

Percentage hemolysis was calculated using the expression $\%$ hemolysis $=\left[A_{405 \mathrm{~nm}}(\right.$ sample $)-A_{405 \mathrm{~nm}}($ negative control $\left.)\right] / A_{405 \mathrm{~nm}}($ positive control)

$A M P s$ antimicrobial peptides, $R B C s$ red blood cells

Since some visible observations were recorded in the rats treated at $1,000 \mathrm{mg} / \mathrm{kg}$ AMPs LR14, the histopathological studies were carried out for that group of treated animals. The microscopic findings suggest that the kidney of the test rats showed a glomerulus with normal size and cellularity. The malpighian tubules were also found to be within normal limits. However, there was mild inflammation around the portal triad in the liver of the test rats in comparison to their respective controls (Fig. 2).

\subsection{Studies on Generation of Immune Response Against AMPs LR14}

Attempts were made to raise antibodies against AMPs LR14 in a rabbit. However, no antibodies could be detected, suggesting that the peptides were not immunogenic.

\section{Discussion}

In the present investigation, the in vitro anti-plasmodial activity of AMPs LR14 against chloroquine-sensitive and resistant strains was demonstrated. The erythrocytic phase is the most important phase in the life cycle of the parasite, when it invades the RBCs of the host and forms an acidic compartment in the lysosome known as the digestive vacuole (DV). The parasite grows in the RBCs and feeds on the hemoglobin of the host cytosol. The parasite accumulates the hemoglobin in the DV and degrades it into its component peptides and heme to form a crystalline polymer hemozoin. Chloroquine works on the fact that the uncharged chloroquine species enters the DV and binds to the hematin, thus preventing its addition into the hemozoin formation. Hematin is a toxic byproduct released during proteolysis of hemoglobin which hinders the detoxification process of the parasite. However, in a chloroquine-resistant strain, mutations in a chloroquine transporter protein do not allow the exit of positively charged chloroquine from the vacuole, thus resulting in a net decrease in chloroquine levels inside the DV [21].

The mechanism by which AMPs LR14 show anti-plasmodial activity on asexual erythrocytic stages is unclear. However, it can be hypothesized that differences in the membrane composition, i.e., interaction of the positively charged peptides with the negatively charged surface molecules of the parasites, might play a significant role in killing of the host cells. Also, changes in the functional and structural characteristics of infected erythrocytes has also been reported by various workers when the plasmodiuminfected cells are targeted with cationic peptides [6]. These modifications include a marked increase in erythrocyte membrane fluidity, alteration of the host cell's lipid, fatty acid, protein composition, and phospholipid distribution, and increased membrane permeability. These modifications result in the formation of erythrocyte membrane channels called "new permeability pathways" (NPPs), thus allowing the selective entry of low molecular weight molecules to the infected erythrocytes [22, 23]. In contrast, uninfected erythrocyte membranes retain asymmetry, and phosphatidylserine is not presented at the external surface prior to a pathological stimulus $[6,24,25]$. AMPs may also have an indirect effect on malaria parasite survival. For example, some synthetic peptides have been shown to kill intracellular blood-stage forms of the malaria parasite [26], whereas some studies have shown that AMPs can induce

Table 2 Acute AMPs LR14 (antimicrobial peptides produced by L. plantarum strain LR/14) administration to Wistar rats: mortality and associated observations of control and test rats over a period of 14 days

\begin{tabular}{lll}
\hline $\begin{array}{l}\text { Dose administered } \\
(\mathrm{mg} / \mathrm{kg} \text { body weight })\end{array}$ & $\begin{array}{l}\text { Cumulative } \\
\text { mortality }\end{array}$ & Toxic signs/symptoms \\
\hline 0 & $0 / 5$ & No treatment-related toxic signs and symptoms/mortality were observed \\
50 & $0 / 5$ & No treatment-related toxic signs and symptoms/mortality were observed \\
300 & $0 / 5$ & No treatment-related toxic signs and symptoms/mortality were observed \\
1,000 & $0 / 5$ & Shivering was noticed in all animals, which subsided within 24 h after the dose was given \\
2,000 & $5 / 5$ & Shivering, ruffled fur, and ataxia were noticed in all animals after dosing. All animals died within \\
& & 4 h after dosing \\
\hline
\end{tabular}


cells to undergo apoptosis [27]. Generally speaking, the positively charged AMPs LR14 are expected to interact electrostatically with the altered and negatively charged plasma membrane of the infected erythrocytes, traversing the membrane of the host and the parasite to reach its target. It has been reported that the presence of non-polar amino acid residues (providing lipophilic anchors) dramatically increases the biological activity, because of the belief that these residues help in their penetration (disruption) through plasma membrane $[6,28,29]$. Therefore, selective toxicity towards P. falciparum and negligible hemolysis of uninfected erythrocytes are the major characteristic properties of AMPs LR14. It should be admitted here that the dose required to kill the parasite was much more than that of chloroquine (the drug used against malaria); nevertheless, AMPs LR14 still holds an important

Table 3 Cumulative body weight of control and test rats after AMPs LR14 (antimicrobial peptides produced by L. plantarum strain LR/14) treatment

\begin{tabular}{llll}
\hline \multirow{2}{*}{$\begin{array}{l}\text { Dose administered }(\mathrm{mg} / \mathrm{kg} \\
\text { body weight })\end{array}$} & \multicolumn{3}{l}{ Weight $(\mathrm{g})$} \\
\cline { 2 - 4 } & Day 1 & Day 2 & Day 3 \\
\hline 0 & $174 \pm 5$ & $181 \pm 5$ & $189 \pm 5.7$ \\
50 & $173 \pm 7.5$ & $179 \pm 8$ & $186 \pm 9$ \\
300 & $174 \pm 1.5$ & $181 \pm 2.5$ & $189 \pm 3.6$ \\
1,000 & $165 \pm 2.5$ & $170 \pm 3$ & $177 \pm 2.6$ \\
2,000 & $162 \pm 2.5$ & & \\
\hline
\end{tabular}
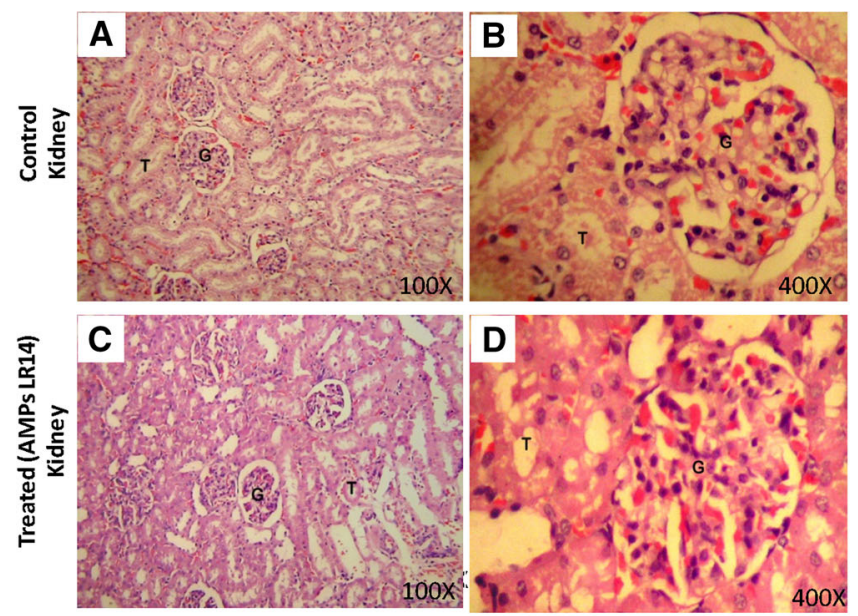

Fig. 2 Histopathological observations in control and test rats (administered with AMPs LR14-1,000 mg/kg). a Control kidney $(H \& E$ stains $\times 100)$ showing normal renal parenchyma. b Control kidney $(H \& E \times 400)$ showing a glomerulus with normal size and cellularity. Malpighian tubules are within normal limits. c Treated kidney (AMPs LR14 1,000 mg/kg) $(\mathrm{H} \& \mathrm{E} \times 100)$ showing normal renal parenchyma. d Treated kidney $(\mathrm{H} \& \mathrm{E} \times 400)$ showing a glomerulus with normal size and cellularity. Tubules are within normal limits. No pathological changes were observed. e Control liver place as it is produced from an L. plantarum strain that has a GRAS (generally regarded as safe) status [11]. Therefore, these peptides should not cause adverse effects on consumption as therapeutics. Besides AMPs showing antiplasmodial activity, it has been reported that some AMPs inhibit the growth of a protozoan parasite, Trypanosoma brucei [30, 31].

The evaluation of AMPs through in vivo toxicity is considered an essential step before its consideration for therapeutic purposes [32]. Animal models have been frequently used to evaluate the in vivo toxicity and to assess the effects of bacteriocins in target organs [33]. The results of acute oral toxicity tests of AMPs LR14 in Wistar rats determined that the $\mathrm{LD}_{50}$ of AMPs LR14 lies between 1,000 and 2,000 mg/ $\mathrm{kg}$. As reported by a number of investigators, the oral $\mathrm{LD}_{50}$ of nisin in rats is $>25 \mathrm{mg} / \mathrm{kg}$ [34], whereas it is $174 \mathrm{mg} / \mathrm{kg}$ in mice $[35,36]$. Also, studies on peptide $\mathrm{P} 34$ on $\mathrm{BALB} / \mathrm{c}$ mice identified the oral $\mathrm{LD}_{50}$ as $>332.3 \pm 0.76 \mathrm{mg} / \mathrm{kg}$ [37]. Most pharmacokinetic studies/biodistribution suggest that oral administration (parental administration) is highly recommended versus other routes of administration [38]; being soluble in water, AMPs LR14 were delivered in an oral form. However, considering the therapeutic application of the peptides, subcutaneous and intravenous administrations need to be evaluated.

Histological studies indicated that AMPs LR14 at $1,000 \mathrm{mg} / \mathrm{kg}$ may result in minimal changes in the liver and no observable changes in the kidney, reflecting its safe use for in vivo administration as a therapeutic. In the liver
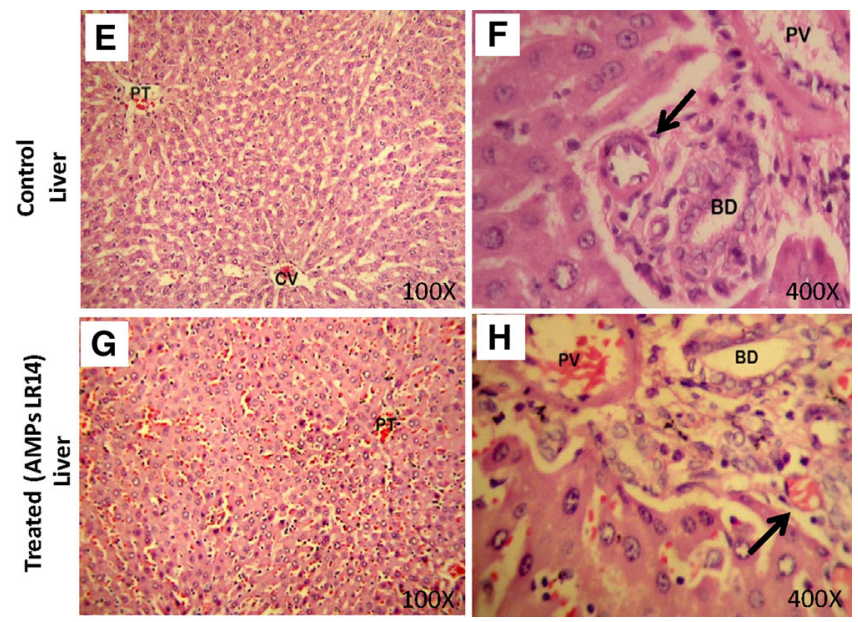

$(H \& E \times 100)$ showing normal liver parenchyma. f Control liver $(\mathrm{H} \& \mathrm{E}$ $\times 400$ ) showing a portal triad (arrow). g Treated liver (AMPs LR14 $1,000 \mathrm{mg} / \mathrm{kg})(\mathrm{H} \& \mathrm{E} \times 100)$ showing normal liver parenchyma. h Treated liver $(H \& E \times 400)$, where the portal area of the liver shows mild inflammatory cell infiltration around the portal triad (arrow). No other pathological changes is seen. AMPs antimicrobial peptides, $B D$ bile duct, $C V$ central vein, $G$ glomerulus, $H \& E$ hematoxylin and eosin, $P T$ portal triad, $P V$ portal vein, $T$ tubules 
of the nisin-treated animals, histological changes suggested some hepatic degeneration [37]. Similarly, another study showed that nisin A administered to rats at a $5 \%$ dietary level for 90 days did not cause any toxicological adverse effect, although statistically significant differences were observed at the tissue level [38]. Comparing these results, AMPs LR14 seem to be a better candidate as they have a higher $\mathrm{LD}_{50}$ than the other tested AMPs.

Moreover, AMPs LR14 failed to elicit an immunogenic response as no antibodies were generated when a rabbit was exposed to these peptides. These results are in accordance with other bacteriocins/AMPs, where a lack of immunogenic response in mice or rabbits has been reported. The antibodies were produced only when these peptides were conjugated with carrier proteins/adjuvants [37, 39, 40].

\section{Conclusion}

All of these results led us to conclude that AMPs LR14 have potential for development of a new antiplasmodial compound. Additionally, this investigation points out that AMPs LR14 can be combined with various antimalarial drugs as a combination therapy that may also delay or hamper the onset of growing resistance to the already available drugs. Such studies can provide an essential therapeutic value for clinical studies against Plasmodium spp. This is a preliminary study that provides important leads for conducting further studies to prove AMPs LR14 as potent anti-malarial peptides. Also, acute toxicity tests provide baseline information about the non-toxic nature of the bioactive peptides.

\begin{abstract}
Acknowledgments This study was supported in part by a grant from the University Grants Commission (UGC) Scholarship, Government of India to RG and DBT fellowship to VR. Acknowledgements are also extended to the Shriram Institute for Industrial Research for the acute oral toxicity study in Wistar rats. We would also like to thank the Rotary Blood Bank, New Delhi, for continuous supply of $\mathrm{O}^{+}$blood. The support provided by the UGC under SAP and the Department of Science and Technology (DST) under FIST programs to the Department of Genetics is also acknowledged.
\end{abstract}

Conflict of interest The authors declare no conflict of interest.

Open Access This article is distributed under the terms of the Creative Commons Attribution Noncommercial License which permits any noncommercial use, distribution, and reproduction in any medium, provided the original author(s) and the source are credited.

\section{References}

1. Kajfasz P. Malaria prevention. Int Marit Health. 2009;60:67-70.

2. Kaushik NK, Sharma J, Sahal D. Anti-plasmodial action of de novo-designed, cationic, lysine-branched, amphipathic, helical peptides. Malar J. 2012;11:256.
3. Xu X, Efremov AK, Li A, Lai L, Dao M, Lim CT, Cao J. Probing the cytoadherence of malaria infected red blood cells under flow. PLoS One. 2013;8:e64763.

4. Tinto H, Rwagacondo C, Karema C, Mupfasoni D, Vandoren W, Rusanganwa E, Erhart A, Van Overmeir C, Van Marck E, D'Alessandro U. In-vitro susceptibility of Plasmodium falciparum to monodesethylamodiaquine, dihydroartemisinin and quinine in an area of high chloroquine resistance in Rwanda. Trans $\mathrm{R}$ Soc Trop Med Hyg. 2006;100:509-14.

5. Mutabingwa TK. Artemisinin-based combination therapies (ACTs): best hope for malaria treatment but inaccessible to the needy! Acta Trop. 2005;3:305-15.

6. Mason AJ, Moussaoui W, Abdelrahman T, Boukhari A, Bertani P, Marquette A, Shooshtarizaheh P, Moulay G, Boehm N, Guerold B, Sawers RJH, Kichler A, Metz-Boutigue M-H, Candolfi E, Prévost $\mathrm{G}$, Bechinger B. Structural determinants of antimicrobial and antiplasmodial activity and selectivity in histidine-rich amphipathic cationic peptides. J Biol Chem. 2009;284:119-33.

7. Lu R, Fasano S, Madayiputhiya N, Morin NP, Nataro J, Fasano A. Isolation, identification, and characterization of small bioactive peptides from Lactobacillus GG conditional media that exert both anti-Gram-negative and Gram-positive bactericidal activity. J Pediatr Gastroenterol Nutr. 2009;49:23-30.

8. O'Sullivan L, Ross RP, Hill C. Potential of bacteriocin-producing lactic acid bacteria for improvements in food safety and quality. Biochimie. 2002;84:593-604.

9. Parada JL, Caron CR, Medeiros ABP, Soccol CR. Bacteriocins from lactic acid bacteria: purification, properties and use as biopreservatives. Braz Arch Biol Technol. 2007;50:521-42.

10. Hancock RE. Cationic peptides: effectors in innate immunity and novel antimicrobials. Lancet Infect Dis. 2001;1:156-64.

11. Gálvez A, Abriouel H, López RL, Omar NB. Bacteriocin-based strategies for food biopreservation. Int $\mathrm{J}$ Food Microbiol. 2007;120:51-70.

12. Adebayo CO, Aderiye BI. Antifungal activity of bacteriocins of lactic acid bacteria from some Nigerian fermented foods. Res J Microbiol. 2010;5:1070-82.

13. Kjos M, Borrero J, Opsata M, Birri DJ, Holo H, Cintas LM, Snipen L, Hernández PE, Nes IF, Diep DB. Target recognition, resistance, immunity and genome mining of class II bacteriocins from Gram-positive bacteria. Microbiology. 2011;157:3256-67.

14. Hodgson E. A textbook of modern toxicology. Hoboken: Wiley; 2004.

15. Tiwari SK, Srivastava S. Characterization of a bacteriocin from Lactobacillus plantarum strain LR/14. Food Biotechnol. 2008;22:247-61.

16. Tiwari SK, Srivastava S. Purification and characterization of plantaricin LR14: a novel bacteriocin produced by Lactobacillus plantarum LR/14. Appl Microbiol Biotechnol. 2008;79:759-67.

17. Gupta R, Sarkar S, Srivastava S. In vivo toxicity assessment of antimicrobial peptides (AMPs LR14) derived from Lactobacillus plantarum strain LR/14 in Drosophila melanogaster. Probiot Antimicrob Proteins. 2014;6:59-67.

18. Gupta R, Srivastava S. Antifungal effect of antimicrobial peptides (AMPs LR14) derived from Lactobacillus plantarum strain LR/ 14 and their applications in prevention of grain spoilage. Food Microbiol. 2014;42:1-7.

19. Desjardins RE, Canfield CJ, Haynes JD, Chulay JD. Quantitative assessment of antimalarial activity in vitro by a semiautomated microdilution technique. Antimicrob Agents Chemother. 1979;16:710-8.

20. Krugliak M, Feder R, Zolotarev VY, Gaidukov L, Dagan A, Ginsburg H, Mor A. Antimalarial activities of dermaseptin S4 derivatives. Antimicrob Agents Chemother. 2000;44:2442-51.

21. Chinappi M, Via A, Paolo M, Tramontano A. On the mechanism of chloroquine resistance in Plasmodium falciparum. Plos One. 2010;5:e14064. 
22. Pouvelle B, Spiegel R, Hsiao L, Howard RJ, Morris RL, Thomas AP, Taraschi TF. Direct access to serum macromolecules by intraerythrocytic malaria parasites. Nature. 1991;353:73-5.

23. Biagini GA, Ward SA, Bray PG. Malaria parasite transporters as a drug-delivery strategy. Trends Parasitol. 2005;21:299-301.

24. Gelhaus C, Jacobs T, Andra J, Leippe M. The antimicrobial peptide NK-2, the core region of mammalian NK-lysin, kills intraerythrocytic Plasmodium falciparum. Antimicrob Agents Chemother. 2008;52:1713-20.

25. Mohandas N, Gallagher PG. Red cell membrane: past, present, and future. Blood. 2008;112:3939-48.

26. Ghosh JK, Shaool D, Guillaud P, Ciceron L, Mazier D, Kustanovich I, Shai Y, Mor A. Selective cytotoxicity of dermaseptin S3 toward intraerythrocytic Plasmodium falciparum and the underlying molecular basis. J Biol Chem. 1997;272:31609-16.

27. Risso A, Zanetti M, Gennaro R. Cytotoxicity and apoptosis mediated by two peptides of innate immunity. Cell Immunol. 1998;189:107-15.

28. Liu Z, Brady A, Young A, Rasimick B, Chen K, Zhou C, Kallenbach NR. Length effects in antimicrobial peptides of the (RW)n series. Antimicrob Agents Chemother. 2007;51:597-603.

29. Pérez-Picaso L, Velasco-Bejarano B, Aguilar-Guadarrama AB, Argotte-Ramos R, Rios MY. Antimalarial activity of ultra-short peptides. Molecules. 2009;14:5103-14.

30. McGwire BS, Olson CL, Tack BF, Engman DM. Killing of African trypanosomes by antimicrobial peptides. J Infect Dis. 2003;188:146-52.

31. Arrighi RBG, Ebikeme C, Jiang Y, Ranford-Cartwright L, Barrett MP, Langel Ü, Faye I. Cell penetrating peptide TP10 shows broad-spectrum activity against both Plasmodium falciparum and Trypanosoma brucei brucei. Antimicrob Agents Chemother. 2008;52:3414-7.
32. Lohans CT, Vederas JC. Development of class IIa bacteriocins as therapeutic agents. Int J Microb. Int J Microbiol. 2012;2012: 386410.

33. Mota-Meira M, Morency H, Lavoie MC. In vivo activity of mutacin B-Ny266. J Antimicrob Chemother. 2005;56:869-71.

34. Frazer AC, Sharratt M, Hickman JR. The biological effect of food additives-nisin. J Sci Food Agric. 1962;13:32-42.

35. Hara S, Yakazu K, Nakakawaji K, Takeuchi T, Kobayashi T, Sata M, Imai Z, Shibuya T. An investigation of toxicity of nisin. J Tokyo Med Univ. 1962;20:176.

36. Opinion of the Scientific Panel on Food Additives, Flavourings, Processing Aids and Materials in Contact with Food on a request from the Commission related to: the use of nisin (E 234) as a food additive. EFSA Journal 2006;314:1-16.

37. Vaucher RA, Gewehr CCV, Correa APF, Sant'Anna V, Ferreira $\mathrm{J}$, Brandelli A. Evaluation of the immunogenicity and in vivo toxicity of the antimicrobial peptide P34. Int $\mathrm{J}$ Pharm. 2011;421:94-8.

38. Hagiwara A, Imai N, Nakashima H, Toda Y, Kawabe M, Furukawa F, Delves Broughton J, Yasuhara K, Hayashi S. A 90-day oral toxicity study of nisin A, an anti-microbial peptide derived from Lactococcus lactis subsp. lactis, in F344 rats. Food Chem Toxicol. 2010;48:2421-8.

39. Martínez JM, Martínez MI, Herranz C, Suárez A, Fernández MF, Cintas LM, Rodríguez JM, Hernández PE. Antibodies to a synthetic 1-9-N-terminal amino acid fragment of mature pediocin PA-1: sensitivity and specificity for pediocin PA-1 and cross-reactivity against class IIa bacteriocins. Microbiology. 1999;145:2777-87.

40. Gupta SM, Aranha CC, Reddy KVR. Evaluation of developmental toxicity of microbicide nisin in rats. Food Chem Toxicol. 2008;46:598-603. 